ISSN : 2406-7415

e-ISSN : 2655-9919

JURNAL AKUNTANSI DAN BISNIS KRISNADWIPAYANA

Vol. 7 No. 1 (Januari - April) 2020

DOI: http://dx.doi.org/10.35137/jabk.v7i1.374

\title{
PENGARUH PENGENDALIAN INTERNAL DAN BUKTI AUDIT TERHADAP OPINI AUDIT \\ (Studi Empiris di Kantor Akuntan Publik di Jakarta Timur)
}

\author{
Ayu Ratna Sari ${ }^{1}$ \\ ${ }^{1}$ Fakultas Ekonomi Universitas Krisnadwipayana \\ Jalan Unkris Jatiwaringin Jakarta Timur \\ Herry Winarto ${ }^{2}$ \\ ${ }^{2}$ Fakultas Ekonomi Universitas Krisnadwipayana \\ Jalan Unkris Jatiwaringin Jakarta Timur \\ Email : herry winarto45@ yahoo.com
}

\begin{abstract}
The population in this study amounted to $40 \mathrm{KAP}$ in the East Jakarta area. The sample in this study uses Cluster Sampling, with the criteria for respondents submitted to the Director of Public Accountants by IAI. Data obtained by collecting questionnaires directly to respondents as many as 42 and 42 returned questionnaires, as well as 38 questionnaires that can be processed. Internal Control and Audit Evidence have a significant and positive effect on Audit Opinion and simultaneous results indicate that the variable Internal Control and Audit Evidence contribute significantly and positively to Audit Opinion. This can be seen from the results of the coefficient of determination (R2 test) of 67.8\%.
\end{abstract}

Keywords: Internal Control, Audit Evidence, Audit Opinion

\section{PENDAHULUAN}

Salah satu profesi
kepercayaan masyarakat $\begin{array}{r}\text { adalah } \\ \text { profesi akuntan publik. dari profesi }\end{array}$
akuntan publik, masyarakat
mengharapkan penilaian yang bebas
dan tidak memihak terhadap
informasi yang disajikan oleh
manajemen perusahaan dalam bentuk
laporan keuangan. Profesi akuntan
publik bertanggung jawab untuk
menaikkan tingkat keandalan laporan
keuangan perusahaan, sehingga
masyarakat dapat memperoleh
informasi keuangan yang handal
sebagai dasar pengambilan
keputusan. Audit merupakan suatu
proses pemeriksaan independen yang
memeriksa laporan keuangan suatu
organisasi untuk memberikan suatu
pendapat mengenai kewajaran dan

kesesuaiannya dengan prinsip akuntansi yang berlaku umum yang dalam penelitian selanjutnya ditulis sebagai opini audit. Tujuan akhir dari proses audit adalah menghasilkan laporan audit, laporan audit inilah yang akan digunakan oleh auditor untuk menyampaikan pernyataan atau pendapatnya (opini) kepada pemakai laporan keuangan sehingga bisa dijadikan acuan bagi pemakai laporan keuangan dalam membaca sebuah laporan. Keandalan laporan keuangan dapat dicapai apabila didukung dengan pengendalian internal yang efektif. Audit yang berkualitas akan mampu mendeteksi penyimpangan dan menginformasikan secara tepat kepada manajemen, dan manajemen dapat merespon atau menindaklanjuti adanya kelemahan tersebut secara 
ISSN : 2406-7415

e-ISSN : 2655-9919

JURNAL AKUNTANSI DAN BISNIS KRISNADWIPAYANA

Vol. 7 No. 1 (Januari - April) 2020

DOI: http://dx.doi.org/10.35137/iabk.v7i1.374

tepat, sehingga kelemahan dapat

diperbaiki dan tidak terulang

kembali. Kemudian bukti audit juga

sangat berperan penting dalam pemeriksaan laporan keuangan perusahaan, oleh sebab itu seorang auditor harus mempunyai kemampuan untuk mengumpulkan dan menganalisa bukti-bukti audit dengan baik, sehingga mamadai untuk dapat merumuskan sebuah opini yang tepat. Seorang akuntan publik juga harus jujur tidak hanya terhadap manajemen dan pemilik perusahaan tetapi juga terhadap investor, kreditur dan pihak lain karena hasil laporan keuangan yang dihasilkan oleh audit sangat diperlukan untuk menjadi dasar dalam pengambilan keputusan untuk berinvestasi atau tidak. Oleh sebab itu, audit harus dilakukan sebaikbaiknya. Karena tidak dipungkiri adanya skandal yang terjadi yang mempertanyakan keandalan laporan keuangan tersebut contohnya, kasus mega skandal Enron dan Worldcorn di USA, yang melibatkan salah satu Big Four, yaitu Arthur Andersen CPA, World Com, Tyco, Global Crossing, Adelphia dan Walt Disney. Skandal didalam negeri, pada tahun 1998 terlihat dari akan diambilnya tindakan oleh Majelis Kehormatan Ikatan Akuntan Indonesia (IAI) terhadap 10 Kantor Akuntan Publik yang diindikasikan melakukan pelanggaran berat saat mengaudit bank-bank yang dilikuidasi. Tujuan penelitian untuk mengetahui seberapa besar pengaruh variabel independen yaitu pengendalian internal dan bukti audit terhadap variabel dependen yaitu opini audit.

\section{LANDASAN TEORI}

\section{Pengendalian Internal}

Pengendalian internal adalah seperangkat kebijakan dan prosedur untuk melindungi aset perusahaan dari segala bentuk tindakan penyalahgunaan, menjamin tersedianya informasi akuntansi perusahaan yang akurat, serta memastikan bahwa semua ketentuan atau kebijakan manajemen telah dipatuhi sebagaimana mestinya oleh seluruh karyawan perusahaan. Hery (2013:159). Menurut Kumaat (2012:15) pengendalian internal adalah suatu cara untuk mengarahkan, mengawasi dan mengukur sumber daya suatu organisasi. Ia berperan penting untuk mencegah dan mendeteksi penggelapan (fraud) dan melindungi sumber daya organisasi.

Menurut Rahayu dan Suhayati (2012:221) Pengendalian internal adalah suatu proses, yang dipengaruhi oleh dewan komisaris, manajemen, dan personel lainnya dalam suatu entitas, yang dirancang untuk memberikan keyakinan memadai guna mencapai tujuantujuan berikut ini : a). Keandalan laporan keuangan, b). Menjaga kekayaan dan catatan organisasi c). Kepatuhan terhadap hukum dan peraturan dan d). Efektivitas dan efisiensi operasi

\section{Tujuan Pengendalian Internal}

Menurut Institut Akuntan Publik Indonesia (2012:319) Tujuan dari pengendalian internal adalah sebagai berikut : 1). Keandalan laporan keuangan Umumya, 2). 
ISSN : 2406-7415

e-ISSN : 2655-9919

JURNAL AKUNTANSI DAN BISNIS KRISNADWIPAYANA

Vol. 7 No. 1 (Januari - April) 2020

DOI: http://dx.doi.org/10.35137/iabk.v7i1.374

Efektivitas dan efisiensi operasi . 3).

Kepatuhan terhadap hukum dan peraturan yang berlaku.

\section{Prinsip-Prinsip pengendalian internal}

Untuk dapat mencapai tujuan pengendalian internal, suatu sistem harus memenuhi enam prinsip dasar yang meliputi:

1. Pemisahan fungsi, Tujuan utama pemisahan fungsi untuk menghindari dan melaksanakanpengawasan segera atas kesalahan atau ketidakberesan.

2. Prosedur pemberian wewenang, Tujuan prinsip ini adalah untuk menjamin bahwa transaksi telah disetujui oleh orang yang berwenang.

3. Prosedur dokumentasi, Dokumentasi yang sangat penting untuk menciptakan sistem pengendalian internal yang efektif.

4. Prosedur dan catatan akuntansi, Tujuan pengendalian ini adalah agar dapat disiapkannya catatancatatan akuntansi yang diteliti secara cepat dan tepat serta data akuntansi dapat dilaporkan kepada pihak yang menggunakan secara tepat waktu.

5. Pengawasan fisik, Berhubungan dengan penggunaan alat-alat mekanis dan elektronis dalam pelaksanaan dan pencatatan transaksi.

6. Pemeriksaan internal secara bebas, Menyangkut perbandingan antara catatan asset dengan asset yang betul-betul ada.

\section{Faktor - faktor penghambat pengendalian internal.}

Marshall dan Steinbart (2012:30) berikut ini faktor-faktor yang dapat menghambat suatu pengendalian internal, yakni sebagai berikut :

1. Persekongkolan (Collusion)

Persekongkolan dapat

menghancurkan pengendalian

internal yang bagaimanapun

baiknya.

2. Biaya dan Manfaat Pengendalian internal

Memiliki banyak sistem pengendalian internal akan banyak menghabiskan biaya jika sistem tersebut tidak efisien untuk perusahaan.

3. Kelemahan Manusia

Banyak penyelewengan yang terjadi pada pengendalian internal yang secara teoritis sudah baik. Karena manusia sebagai pelaksananya yang mempunyai keterbatasan dan kelemahan-kelemahan.

\section{Pengertian Audit}

Menurut Ikatan Akuntansi Indonesia atau sering disingkat dengan IAI (2012:100) auditing adalah proses pengumpulan data dan pengevaluasian bahan bukti tentang informasi yang dapat diukur mengenai suatu entitas ekonomi yang dilakukan oleh seseorang auditor yang berkompeten dan juga independen untuk dapat menetukan danmelaporkan kesesuaian informasi yang dimaksud dengan kriteriakriteria yang telah ditetapkan. Auditing adalah pengumpulan dan evaluasi bukti mengenai informasi 
ISSN : 2406-7415

e-ISSN : 2655-9919

JURNAL AKUNTANSI DAN BISNIS KRISNADWIPAYANA

Vol. 7 No. 1 (Januari - April) 2020

DOI: http://dx.doi.org/10.35137/iabk.v7i1.374

untuk menentukan dan melaporkan derajat kesesuaian antara informasi tersebut dengan kriteria yang telah ditetapkan Elder (2013:4).

\section{Pengertian Bukti Audit}

Menurut Mulyadi (2014:74) menyatakan bahwa Segala informasi yang mendukung angka-angka atau informasi lain yang disajikan dalam laporan keuangan, yang dapat digunakan oleh auditor sebagai dasar untuk menyatakan pendapatnya. Menurut Arens, Elder dan Beasley (2012:225) mengemukakan bahwa sebagai setiap informasi yang digunakan oleh auditor untuk menentukan apakah informasi yang diaudit telah dinyatakan sesuai dengan kriteria yang ditetapkan.

\section{Jenis-jenis Bukti Audit.}

Menurut Mulyadi (2013:126) dalam menentukan prosedur audit mana yang akan digunakan, diperlukan bahan bukti audit, pengumpul bukti yang tersedia bagi auditor untuk mendukung tujuan audit, menjelaskan antara tujuan audit yang bersifat umum dan khusus.

1. Tujuan Audit Umum. Pada dasarnya tujuan umum audit ialah untuk menyatakan pendapat atas kewajaranposisi keuangan dengan prinsip akuntansi yang berlaku umum.

2. Tujuan audit khusus. Tujuan audit khusus lebih ditujukan untuk pengujian terhadap pospos yang terdapat dalam laporan keuangan yang merupakan asersi manajemen.
Auditor

harus

mempertimbangkan

tingkat

keandalan serta jenis bukti yang akan dikumpulkan sesuai dengan tujuan dan lingkup audit.

1. Bukti Fisik . Bukti fisik dapat diperoleh melalui pengamatan langsung yang dilakukan oleh auditor terhadap orang, property, atau kejadian.

2. Bukti Dokumen Bukti dokumen terdiri dari informasi yang diciptakan seperti surat, kontrak, catatan akuntansi, faktur, serta informasi manajemen atas kinerja.

3. Bukti Kesaksian. Bukti kesaksian(testimonial) diperoleh melalui permintaan keterangan, wawancara atau kuesioner.

4. Bukti Analitis. Bukti analitis didapat dari data yang telah diverifikasi dan dianalisis.

\section{Opini Audit.}

Menurut Ardiyos (2016:661) dalam kamus besar akuntansi opini audit adalahlaporan yang dibuat oleh pemeriksa (auditor) setelah memeriksa penemuan-penemuan yang berkenaan dengan laporan keuangan suatu perusahaan.

Menurut Mulyadi(2012:140) menyatakan bahwa opini audit merupakan pernyataan auditor terhadap pendapat mengenai kewajaran laporan keuangan auditan, dalam semua hal yang material, yang didasarkan atas kesesuaian penyusunan laporan keuangan tersebut dengan prinsip akuntansi yang berlaku umum. 
ISSN : 2406-7415

e-ISSN : 2655-9919

JURNAL AKUNTANSI DAN BISNIS KRISNADWIPAYANA

Vol. 7 No. 1 (Januari - April) 2020

DOI: http://dx.doi.org/10.35137/iabk.v7i1.374

Jenis-jenis opini audit.

Menurut Standar Professional Akuntan Publik (2012) PSA No. 29 SA Seksi 508, ada lima (5) jenis opini auditor, yaitu antara lain: 1). Pendapat Wajar Tanpa Pengecualian (Unqualified Opinion). 2). Pendapat Wajar dengan Pengecualian (Qualified Opinion).

\section{Objek, Lokasi Penelitian}

Objek penelitian yang diteliti dalam penelitian ini adalah Manager dan Supervisor Audit yang bekerja pada Kantor Akuntan Publik (KAP) di Jakarta Timur. Peneliti melakukan penelitian di 10 Kantor Akuntan Publik (KAP) yang berada di Jakarta Timur.

\section{ANALISIS DAN PEMBAHASAN}

Tabel 1 Statistic Deskriptif

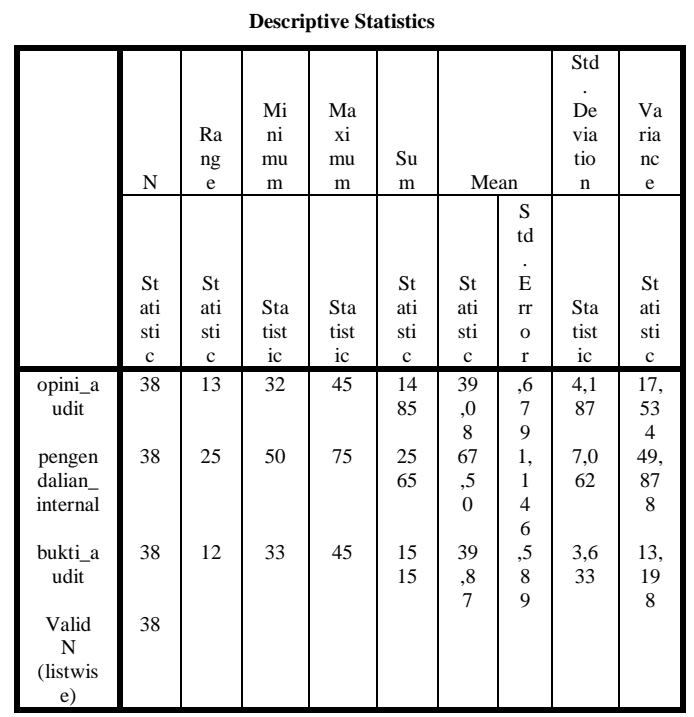

Dari tabel 1 di atas dapat dideskripsikan bahwa jumlah responden (N) ada 38. Dari 38 responden ini pada variabel dependen yaitu opini audit memiliki nilai minimum 32 , nilai maksimum 45 , nilai mean 39,08 , dengan standar deviasi 4,187. Sedangkan pada variabel independen yaitu pengendalian internal memiliki nilai minimum 50, nilai maksimum 75 , nilai mean 67,50 dengan standar deviasi 7,062, dan bukti audit memiliki nilai minimum 33 , nilai maksimum 45, nilai mean 39,87 , dengan standar deviasi 3,633.

\section{Hasil Uji Asumsi Klasik.}

\section{Uji Normalitas.}

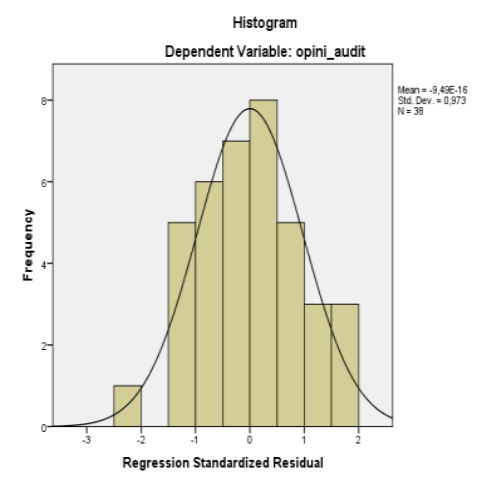

Gambar 1. Hasil Uji Normalitas Dengan Menggunakan Grafik Histogram

Berdasarkan gambar 1 diatas dapat disimpulkan bahwa grafik histogram yang menunjukkan data berdistribusi yang normal karena grafik membentuk seperti lonceng dan tidak miring ke kiri atau ke kanan. Adapun hasil perhitungan uji normalitas dengan melihat dari segi grafik yang ditunjukkan pada gambar grafik p-plot berikut ini: 
Vol. 7 No. 1 (Januari - April) 2020

DOI: httb://dx.doi.org/10.35137/iabk.v7i1.374

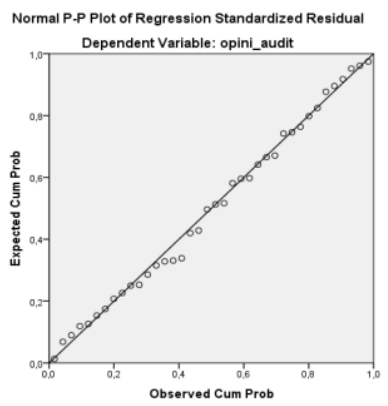

Gambar 2. Hasil Uji Normalitas Dengan Menggunakan Normal PPlot

Berdasarkan gambar 2 diatas dapat terlihat titik-titik menyebar disekitar garis diagonal dan mengikuti arah garis diagonal. Kedua grafik ini menunjukkan bahwa model regresi layak dipakai, maka dapat disimpulkan bahwa model regresi memenuhi asumsi normalitas.

\section{Uji Multikolinieritas.}

Tabel 2. Hasil Uji Multikolinieritas

\begin{tabular}{|l|r|r|}
\hline \multirow{2}{*}{ Model } & \multicolumn{2}{|c|}{$\begin{array}{c}\text { Collinearity } \\
\text { Statistics }\end{array}$} \\
\cline { 2 - 3 } & $\begin{array}{c}\text { Toleranc } \\
\text { e }\end{array}$ & VIF \\
\hline $1 \quad$ (Constant) & & \\
$\quad \begin{aligned} \text { pengendalian_intern } \\
\text { al }\end{aligned}$ &, 978 & 1,02 \\
& & 2 \\
bukti_audit &, 978 & 1,02 \\
& & 2 \\
\hline
\end{tabular}

Berdasarkan table 2 di atas terlihat bahwa perhitungan tolerance menunjukkan tidak ada variabel bebas yang memiliki nilai tolerance lebih dari 0,10 yang berarti tidak ada korelasi antar variabel bebas. Hasil perhitungan variance inflation factor (VIF) juga menunjukkan hal yang sama tidak ada satu variabel bebas yang memiliki nil. ai VIF kurang dari 10. Jadi dapat disimpulkan bahwa tidak ada multikolinieritas antar variabel bebas dalam model regresi.

\section{Uji Heteroskedastisitas.}

Gambar 3. Hasil Grafik Scatterplots

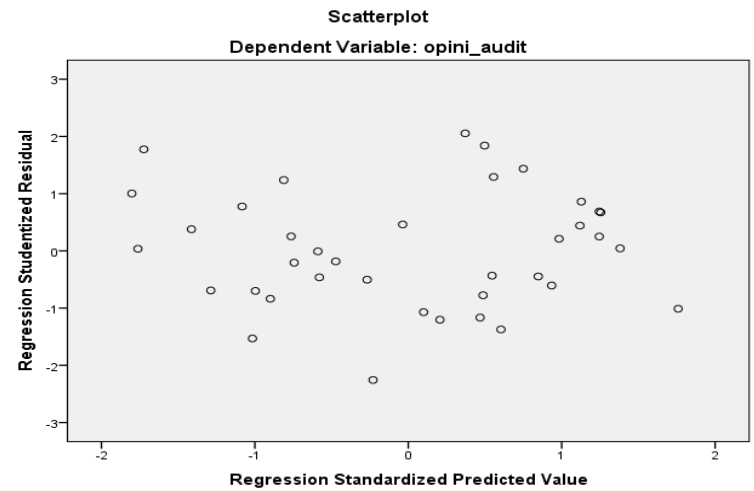

Dari gambar 3 diatas diketahui bahwa sebaran data tidak membentuk pola yang jelas, titik-titik data menyebar diatas dan dibawah angka 0 (nol) pada sumbu Y. Dan dengan demikian dapat disimpulkan bahwa pada model regresi tidak terjadi heteroskedastisitas pada model regresi. 
ISSN : 2406-7415

e-ISSN : 2655-9919

JURNAL AKUNTANSI DAN BISNIS KRISNADWIPAYANA

Vol. 7 No. 1 (Januari - April) 2020

DOI: http://dx.doi.org/10.35137/iabk.v7i1.374

Hasil Uji Hipotesis. Uji Analisis Regresi Linier Berganda.

Tabel 3. Hasil Uji Regresi Linier Berganda

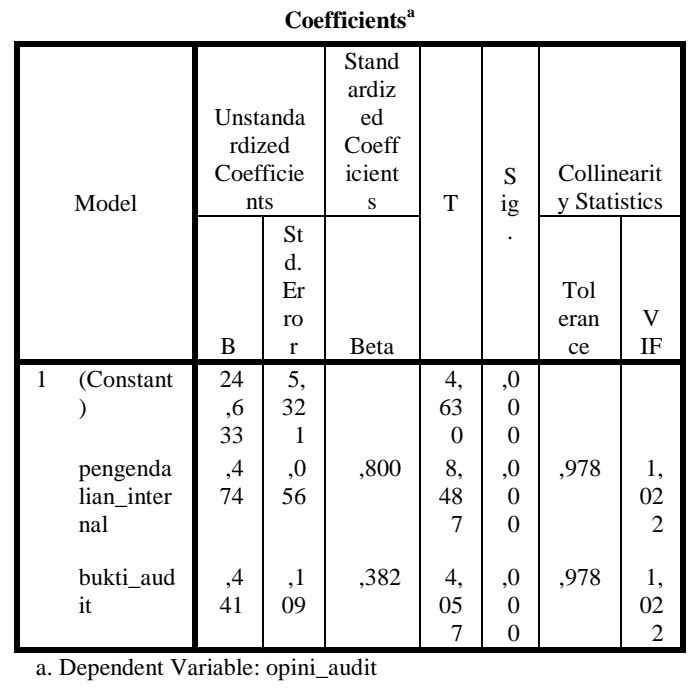

Berdasarkan tabel 3 diatas dapat di ketahui bahwa hasil yang telah diperoleh dari koefisien regresi di atas, maka dapat dibuat suatu persamaan regresi sebagai berikut :

$Y=24,633+0,474\left(X_{1}\right)+0,441$ $\left(\mathbf{X}_{2}\right)$

\begin{tabular}{llll}
\multicolumn{2}{c}{ Dari persamaan } & regresi \\
tersebut dapat dijelaskan & sebagai \\
berikut: (1). & Konstanta & sebesar
\end{tabular} 24,633 menunjukkan tanda positif, hal tersebut dapat diartikan bahwa apabila pengendalian internal $\left(\mathrm{X}_{1}\right)$, dan bukti audit $\left(\mathrm{X}_{2}\right)$ dianggap konstan atau bernilai nol (0), maka opini audit (Y) akan sebesar 24,633. (2).Koefisien regresi pengendalian internal $\left(\mathrm{X}_{1}\right), \quad$ sebesar 0,474 menunjukkan tanda positif, hal tersebut dapat diartikan setiap penambahan nilai pengendalian internal maka akan terjadi peningkatan opini audit yang dihasilkan oleh faktor tersebut sebesar 0,474. (3) Koefisien regresi bukti audit $\left(\mathrm{X}_{2}\right)$, sebesar 0,441 menunjukkan tanda positif, hal tersebut dapat diartikan setiap penambahan nilai bukti audit maka akan terjadi peningkatan opini audit yang dihasilkan oleh faktor tersebut sebesar 0,441.

Uji Koefisien Determinasi $\left(\mathbf{R}^{2}\right)$.

Tabel 4. Hasil Koefisien Determinasi (Uji R ${ }^{2}$ )

\begin{tabular}{|c|c|c|c|c|}
\hline \multicolumn{5}{|c|}{ Model Summary $^{\text {b }}$} \\
\hline $\begin{array}{l}\text { Mode } \\
1\end{array}$ & $\mathrm{R}$ & $\begin{array}{c}\mathrm{R} \\
\text { Squar } \\
\mathrm{e}\end{array}$ & $\begin{array}{l}\text { Adjuste } \\
\text { d R } \\
\text { Square }\end{array}$ & $\begin{array}{c}\text { Std. } \\
\text { Error } \\
\text { of the } \\
\text { Estimat } \\
\text { e }\end{array}$ \\
\hline 1 & $\begin{array}{r}\text {,834 } \\
\text { a }\end{array}$ & 696, & ,678 & 2,375 \\
\hline
\end{tabular}

a. Predictors: (Constant), bukti_audit, pengendalian_internal

b. Dependent Variable: opini_audit.

Berdasarkan tabel 4 diatas diketahui nilai koefisien korelasi berganda (R) sebesar 0,834. Ini menunjukkan bahwa variabel pengendalian internal dan bukti audit terhadap opini audit mempunyai hubungan yang kuat. Hasil pada tabel diatas juga menunjukkan bahwa nilai koefisien determinasi ( $R$ Square) sebesar 0,696 dan nilai determinasi yang sudah disesuaikan (Adjusted $R$ Square) adalah 0,678. Hal ini berarti $67,8 \%$ variasi dari dependen yaitu opini audit bisa dijelaskan oleh variasi independen yaitu pengendalian internal dan bukti audit. Sedangkan sisanya $32,2 \%$ (100\%-67,8\%) dijelaskan oleh variabel lain yang tidak disertakan dalam penelitian ini. 
DOI: http://dx.doi.org/10.35137/jabk.v7i1.374

\section{Hasil Uji Secara Parsial (Uji t).}

Tabel 5. Hasil Uji Statistik t Untuk Variabel Pengendalian Internal Terhadap Opini Audit

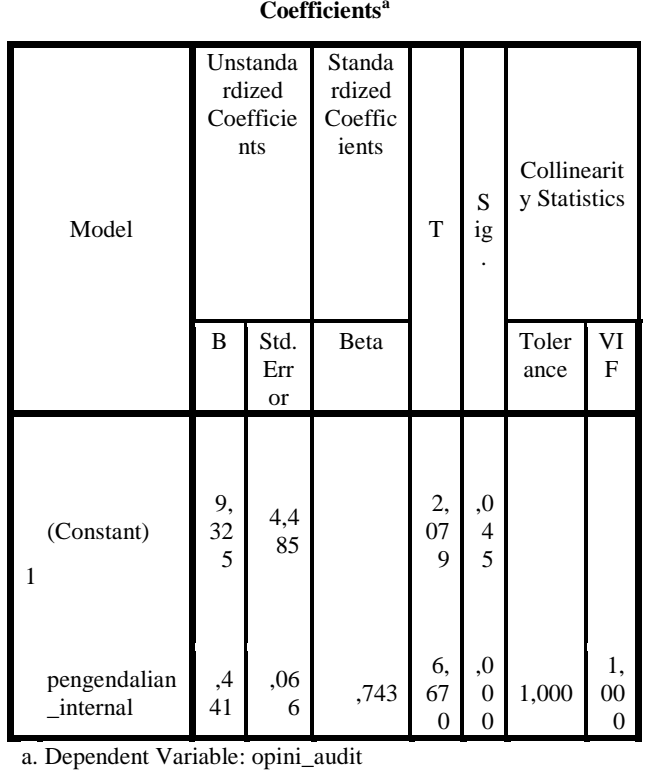

Berdasarkan tabel 5 yang diatas menunjukkan nilai $\mathrm{t}$ untuk variabel pengendalian internal sebesar 6,670 dengan tingkat signifikansi sebesar 0,000. Nilai $\mathrm{t}$ hitung selanjutnya dikonsultasikan dengan nilai $t$ tabel yang didasarkan pada $\mathrm{dk}=\mathrm{n}-1$ (38-1) dan taraf kesalahannya $\mathrm{a}=5 \%$. Berdasarkan $\mathrm{t}$ tabel bila $\mathrm{dk}=37$ dan $\mathrm{a}=5 \%$, maka diperoleh $\mathrm{t}$ tabel sebesar 1,687. Sehingga dapat disimpulkan bahwa $t$ hitung lebih besar dari t tabel yakni $6,670>1,687$ dengan probabilitas jauh lebih kecil dari 0,05. Karena itu dapat disimpulkan bahwa $\mathrm{Ha}$ diterima Ho ditolak yang berarti pengendalian internal berpengaruh dan signifikan terhadap opini audit.
Model Summary ${ }^{b}$

\begin{tabular}{|l|c|c|c|c|}
\hline $\begin{array}{l}\text { Mod } \\
\text { el }\end{array}$ & $\mathrm{R}$ & $\begin{array}{c}\mathrm{R} \\
\text { Squa } \\
\text { re }\end{array}$ & $\begin{array}{c}\text { Adjust } \\
\text { ed R } \\
\text { Square }\end{array}$ & $\begin{array}{c}\text { Std. } \\
\text { Error } \\
\text { of the } \\
\text { Estima } \\
\text { te }\end{array}$ \\
\hline 1 & $\begin{array}{r}, 74 \\
3^{\mathrm{a}}\end{array}$ &, 553 &, 540 & 2,839 \\
\hline
\end{tabular}

a. Predictors: (Constant), pengendalian_internal

b. Dependent Variable: opini_audit Sumber data yang diolah 2017

Kemudian hasil uji koefisien determinasi di atas nilai adjusted $\mathrm{R}^{2}$ sebesar 0,540. Hal ini berarti hanya mempengaruhi variabel opini audit sebesar 54\% saja. Selanjutnya dari persamaan regresi linear berganda dapat dilihat arah hubungan yang dihasilkan pengendalian internal terhadap opini audit dengan asumsi variabel lain konstan yaitu : $\mathrm{Y}=9,325+0,441 \quad(\mathrm{x} 1)$. Hasil tersebut menunjukkan adanya hubungan positif dari variabel pengendalian internal yang menyebabkan kenaikkan sebesar 0,441 terhadap opini audit. Ha1 :

Pengendalian internal secara parsial mempunyai pengaruh dan signifikan terhadap opini audit. Hal ini dapat kita gambarkan melalui ilustrasi berikut. Bahwa pada saat auditor dengan tingkat pengendalian internal yang tinggi dan memiliki pengendalian internal yang baik di bidangnya, maka auditor akan mudah dalam memberikan opini audit. Sebaliknya, jika tingkat pengendalian internal yang rendah dan tidak memiliki pengendalian internal yang baik di bidangnya, maka auditor 
DOI: http://dx.doi.org/10.35137/iabk.v7i1.374

tidak akan mudah dalam memberikan opini auditnya secara baik. 1). Hasil uji pengaruh bukti audit terhadap opini audit

Tabel 6. Hasil Uji Statistik t Untuk Variabel Bukti Audit Terhadap Opini Audit

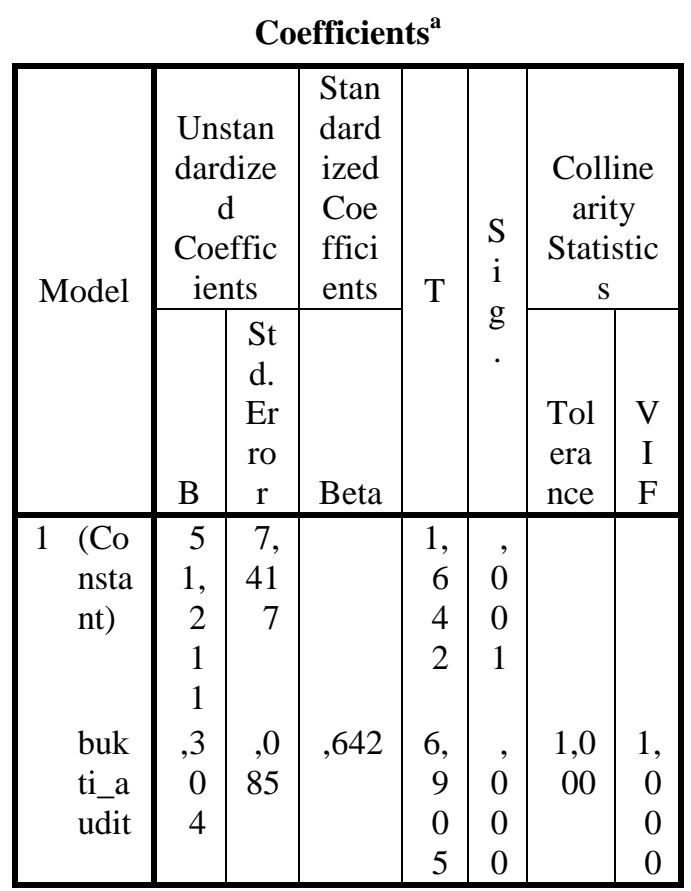

a. Dependent Variable: opini_audit

Berdasarkan tabel 6 yang diatas menunjukkan nilai $\mathrm{t}$ untuk variabel bukti audit sebesar 6,905 dengan tingkat signifikansi sebesar 0,000 . Nilai $t$ hitung selanjutnya dikonsultasikan dengan nilai $\mathrm{t}$ tabel yang didasarkan pada $\mathrm{dk}=\mathrm{n}-1$ (381) dan taraf kesalahannya $a=5 \%$. Berdasarkan $\mathrm{t}$ tabel bila $\mathrm{dk}=37 \mathrm{dan}$ $\mathrm{a}=5 \%$, maka diperoleh $\mathrm{t}$ tabel sebesar 1,687. Sehingga dapat disimpulkan bahwa $\mathrm{t}$ hitung lebih besar dari t tabel yakni 6,905 > 1,687 dengan probabilitas jauh lebih kecil dari 0,05. Karena itu dapat disimpulkan bahwa Ha diterima Ho ditolak yang berarti bukti audit berpengaruh dan signifikan terhadap opini audit.

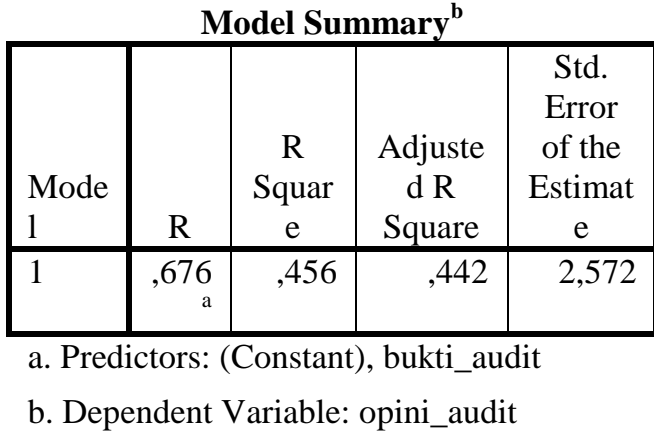

Sumber data yang diolah 2017

Kemudian hasil uji koefisien determinasi di atas nilai adjusted $\mathrm{R}^{2}$ sebesar 0,442. Hal ini berarti hanya mempengaruhi variabel opini audit sebesar $44,2 \%$ saja. Selanjutnya dari persamaan regresi linear berganda dapat dilihat arah hubungan yang dihasilkan bukti audit terhadap opini audit dengan asumsi variabel lain konstan yaitu : Y $=51,211+$ 0,304 (x2). Hasil tersebut menunjukkan adanya hubungan positif dari variabel bukti audit yang menyebabkan kenaikkan sebesar 0,304 terhadap opini audit. Ha2 : Bukti audit secara parsial mempunyai pengaruh dan signifikan terhadap opini audit. Hal ini dapat kita gambarkan melalui ilustrasi berikut. Bahwa pada saat auditor dengan tingkat bukti audit yang tinggi dan sudah sesuai dengan standarnya, maka auditor akan mudah dalam memberikan opini audit. Sebaliknya, jika tingkat bukti audit yang rendah dan tidak sesuai dengan standarnya, maka auditor tidak akan mudah dalam memberikan opini audit. 


\section{Hasil Uji Secara Simultan (Uji F)}

Tabel 7. Hasil Uji Statistik F (Simultan)

\begin{tabular}{|l|r|r|r|r|r|}
\hline Model & $\begin{array}{c}\text { Sum } \\
\text { of } \\
\text { Squar } \\
\text { es }\end{array}$ & $\begin{array}{c}\text { D } \\
\text { f }\end{array}$ & $\begin{array}{c}\text { Mean } \\
\text { Squar } \\
\text { e }\end{array}$ & F & Sig \\
& & & \\
\hline Regress & 451,3 & 2 & 225,6 & 40,0 &, 00 \\
ion & 94 & 97 & 23 & $0^{\mathrm{b}}$ \\
1 Residua & 197,3 & 3 & 5,639 & & \\
1 & 69 & 5 & & & \\
Total & 648,7 & 3 & & & \\
63 & 7 & & & \\
\hline
\end{tabular}

a. Dependent Variable: opini_audit

b. Predictors: (Constant), bukti_audit, pengendalian_internal

Sumber data yang diolah 2017

Berdasarkan tabel 7 yang diatas menunjukkan bahwa hasil uji F dapat dilihat pada tabel di atas nilai $F_{\text {hitung diperoleh sebesar } 40,023>}$ $F_{\text {tabel }}$ sebesar 2,47(didapat dari $\mathrm{df}=$ $\mathrm{n}-1$ atau $=38-1=37$ )dengan tingkat signifikan $0,000<0,05$. Karena tingkat signifikansi lebih kecil dari 0,05, maka $\mathrm{H}_{\mathrm{O}}$ ditolak dan $\mathrm{Ha}$ diterima.Ha1 : Pengendalian internal dan bukti audit secara simultan mempunyai pengaruh dan signifikan terhadap opini audit secara bersamasama.

\section{PEMBAHASAN}

Berdasarkan hasil penelitian yang telah dilakukan, diperoleh Hasil pengujian hipotesis secara parsial (uji t) pengendalian internal, dapat disimpulkan bahwa pengendalian internal secara parsial berpengaruh signifikan terhadap opini audit. hal ini menunjukkan bahwa auditor yang memiliki pengendalian internal yang baik maka akan muda memberikan opini auditnya. Hasil pengujian hipotesis secara parsial (uji t) bukti audit, dapat disimpulkan bahwa bukti audit secara parsial berpengaruh signifikan terhadap opini audit. Hal ini menunjukkan bahwa auditor yang memiliki bukti audit yang sesuai dengan standarnya maka dapat memberikan opini audit yang lebih baik. Hasil pengujian hipotesis secara simultan (uji F) menunjukkan bahwa pengendalian internal dan bukti audit secara bersama-sama berpengaruh secara signifikan terhadap opini audit. Semakin baik tingkat pengendalian internal dan bukti audit yang di miliki auditor maka semakin baik pula opini auditnya. Hasil pengujian hipotesis secara simultan (uji F) pada penelitiandiketahui Ho ditolak, sehingga dapat disimpulkan bahwa variabel pengendalian internal dan bukti audit, secara bersama-sama berpengaruh signifikan terhadap opini audit. Hal ini diperkuat dengan nilai $F$ hitung.Hasil pengujian Koefisien Determinasi $\left(\mathrm{R}^{2}\right)$ diketahui bahwa pengaruh yang dihasilkan dari variabel independen yaitu pengendalian internal dan bukti audit terhadap variabel dependen yaitu opini audit sebesar $67,8 \%$ sedangkan sisanya sebesar $32,2 \%$ dipengaruhi oleh variabel lain yang diduga memiliki pengaruh terhadap opini audit. Oleh karena itu selain memperhatikan variabel-variabel yang mempengaruhi opini audit, seorang akuntan publik juga harus memperhatikan variabel-variabel lain yang dapat dijadikan sebagai pertimbangan dalam meningkatkan opini audit seperti akuntabilitas, independensi, profesionalisme, 
ISSN : 2406-7415

e-ISSN : 2655-9919

JURNAL AKUNTANSI DAN BISNIS KRISNADWIPAYANA

Vol. 7 No. 1 (Januari - April) 2020

DOI: http://dx.doi.org/10.35137/jabk.v7i1.374

skeptisme profesional dan lainlainnya.

\section{KESIMPULAN DAN SARAN}

\section{KESIMPULAN}

Berdasarkan hasil analisis data yang telah dilakukan maka dapat diketahui kesimpulan sebagai berikut: 1).Pengendalian internal (X1) terbukti memiliki pengaruh signifikan terhadap opini audit. Hal ini dapat dibuktikan dari hasil pengujian uji t yaitu nilai signifikansi sebesar $0,000<0,05$ dan nilai $t$ untuk variabel pengendalian internal sebesar 6,670 dengan tingkat signifikansi sebesar 0,000 . Hal ini dapat di tunjukkan dari auditor yang memiliki pengendalian internal yang baik di bidangnya, maka seorang auditor dapat dengan mudah dalam memberikan opini auditnya yang lebih baik. 2). Bukti audit (X2) terbukti memiliki pengaruh signifikan terhadap opini audit. Hal ini dapat dibuktikan dari hasil pengujian uji $\mathrm{t}$ yaitu nilai signifikan sebesar $0,000<0,05$ dan nilai $t$ untuk variabel bukti audit sebesar 6,905dengan tingkat signifikansi sebesar 0,000. Hal ini dapat di tunjukkan dari auditor yang memiliki bukti audit yang sesuai dengan standarnya, maka seorang auditor dapat dengan mudah dalam memberikan opini auditnya.3). Uji simultan ( Uji f). Pengendalian internal dan bukti audit terbukti memiliki pengaruh signifikan terhadap opini audit, nilai signifikan sebesar $0,000<0,05$ dan nilai $f$ untuk variabel pengendalian internal dan bukti audit terhadap opini audit sebesar 40,023dengan tingkat signifikansi sebesar 0,000. Hal ini

dapat di tunjukkan dari auditor yang memiliki pengendalian internal yang baik dan bukti audit yang sesuai dengan standarnya, maka seorang auditor dapat dengan mudah dalam memberikan opini auditnya.

\section{SARAN}

Berdasarkan hasil penelitian yang telah dilakukan, maka peneliti memberikan saran guna menyempurnakan keterbatasan yang ada agar penelitian selanjutnya menjadi lebih baik, ada beberapa saran yang diharapkan dan dapat bermanfaat bagi penelitian selanjutnya, antara lain: 1). Bagi peneliti a). Untuk penelitian selanjutnya, sebaiknya menggunakan metode tambahan seperti wawancara langsung dengan responden untuk mengetahui kondisi responden yang sebenarnya berdasarkan jawaban yang diberikan. b). Untuk penelitian selanjutnya, sebaiknya menambah jumlah variabel yang akan diteliti dengan variabel lain yang diduga dapat mempengaruhi opini audit seperti akuntabilitas, independensi, profesionalitas, dan lain-lain.2). Bagi auditor KAP. Hasil penelitian ini diharapkan dapat menjadi acuan bagi auditor dalam memberikan opini audit. Diharapkan dengan memiliki pengendalian internal dan bukti audit dapat mendukung pembuatan opini audit untuk menjadi lebih baik lagi.

\section{DAFTAR PUSTAKA}

Agoes, Sukrisno. 2013. Auditing Petunjuk Praktis Pemeriksaan Akuntan Oleh Akuntan Publik. Jilid 1. Edisi Keempat. Jakarta: Salemba Empat. 
DOI: http://dx.doi.org/10.35137/jabk.v7i1.374

Anggreini S. 2013. Pengaruh Sistem

Pengendalian

Intern

Terhadap Kualitas Laporan

Keuangan Pemerintah Kota

Bekasi. Skripsi. Bekasi:

Universitas Bayangkara Jakarta Raya.

Ardiyos. 2016. Kamus Besar Akuntansi. Jakarta: Citra Harta Prima

Arens, Elder, dan Beasley. 2012. Auditing dan Jasa Assurance Pendekatan Terintegrasi. Jilid

1. Edisi 12. Jakarta. Erlangga.

Azhar Susanto .2013. Sistem Informasi Akuntansi.

Bandung: Lingga Jaya

Elder, Randal J., Mark S. Beasly, Alvin A. Arens, dan Amir Abdi Jusuf. 2013. Jasa Auditan dan Assurance. Buku 1, Jakarta: Salemba Empat.

Haryono Jusup. 2012. Dasar-Dasar

Akuntansi. Jilid 2. Yogyakarta

: Bagian Penerbitan Sekolah Tinggi Ilmu YKPN.

Hery. 2013. Auditing (Pemeriksaan

Akuntansi I). Cetakan

Pertama. Jakarta : CAPS

(Center of Academic

Publishing Service)

Ikatan Akuntansi Indonesia (IAI).

2012. Standar Profesional Akuntan Publik (SPAP). Jakarta : Salemba Empat.

Institut Akuntan Publik Indonesia. 2012. Standar Akuntansi

Keuangan. Jakarta : Salemba Empat.

James A Hall. 2012. Accounting Information System

Terjemahaan Dewi Fitriasari). Jakarta. Salemba Empat.

Leonita Agustin M. 2012. Pengaruh bukti audit dan pengendalian internal terhadap opini audit.
Skripsi. Jakarta: Universitas Krisnadwipayana.

Levany, Y. 2013, Pengambilan keputusan, Bahan Ajar Mata Kuliah Sistem Pengendalian Manajemen.

Mulyadi 2014. Audit 2. Edisi keenam Jakarta: Salemba Empat, oleh Auditor Eksternal. Jurnal Akuntansi dan Keuangan. Vol.10 No.1.

Mulyadi. 2012. Sistem Akuntansi. Edisi ke-3, Cetakan ke-5. Penerbit Salemba Empat, Jakarta.

Mulyadi. 2013. Audit 1. Edisi ke-6. Penerbit Salemba Empat. Jakarta

Ni luh ketut shanti antik safitri. 2014. Pengaruh pengendalian internal dan bukti audit terhadap opini audit. Skripsi. Makassar: Universitas Hasanuddin.

Rai I gusti, Agung. 2012. Audit Kinerja Pada Sektor Publik. Jakarta : Grafindo

Romney Marshall and Steinbart. 2012. Accounting Information System (12 Edition). London: Prentice Hall.

Siti Kurnia Rahayu dan Ely Suhayati. 2012. Auditing, Konsep Dasar dan Pedoman Pemeriksaan Akuntan Public. Yogyakarta. Graha Ilmu.

Standar Profesional Akuntan Publik. 2012 - PSA 29 SA Seksi 508. Jakarta.

Suryani dan Helvinda. 2012. Pengaruh pengendalian internal dan risiko audit terhadap opini audit. Skripsi. Palembang: Universitas Bina Darma Palembang. 
ISSN : 2406-7415 e-ISSN : 2655-9919

JURNAL AKUNTANSI DAN BISNIS KRISNADWIPAYANA Vol. 7 No. 1 (Januari - April) 2020 DOI: http://dx.doi.org/10.35137/iabk.v7i1.374 